\title{
Podręczniki szkolne Polskiej Macierzy Zagranicą A EDUKACJA I WYCHOWANIE DZIECI POLSKICH NA OBCZYŹNIE
}

\author{
MarTyna TomiczeK \\ martynatomiczek@wp.pl
}

Ruch migracyjny na stałe wpisał się w polską rzeczywistość. Od wieków kolejne pokolenia Polaków opuszczających ojczyznę (z wielu różnorodnych powodów) doświadczają następstwa procesów migracyjnych. Od wieków również Polacy żyjący poza granicami rodzinnego kraju organizują się, tworząc instytucje polonijne, których zadaniem jest podtrzymanie związków z Rzeczpospolitą. Organizacje polonijne wykorzystując różne środki i narzędzia, dają możliwość „dotykania” polskości i szansę na obcowanie z polskimi wartościami, kulturą i tradycjami.

Celem niniejszego artykułu jest nakreślenie roli, jaką w edukacji i wychowaniu polskich dzieci żyjących na obczyźnie, które w dużym stopniu narażone są na uleganie negatywnym aspektom asymilacji, pełnią podręczniki wydawane przez Polską Macierz Szkolną Zagranicą - jedną z najważniejszych instytucji polonijnych.

\section{DZIECKO W WARUNKACH WIELOKULTUROWOŚCI}

- PROBLEMY TOŻSAMOŚCIOWE, PROCESY AKULTURACJI I ASYMILACJI

Sytuacja dziecka polskiego wychowującego się poza granicami kraju należy do niezwykle skomplikowanych. Na poziom jej złożoności wpływają przede wszystkim problemy związane z kształtowaniem tożsamości i odkrywaniem swojego ,ja” , które w warunkach wielokulturowości może ulec zwielokrotnieniu. Konstruowanie siebie zostaje niejednokrotnie zaburzone przez postępujące procesy asymilacyjne $\mathrm{i}$ ich następstwa.

H. Mamzer w swojej książce Tożsamość w podróży. Wielokulturowość a ksztaltowanie tożsamości jednostki przyjmuje, że trzy zakresy tożsamości można przedstawić w formie hierarchii - wówczas układ wygląda następująco: tożsamość społeczna, tożsamość jednostkowa oraz tożsamość kulturowa ${ }^{1}$.

Źródłem tożsamości społecznej jest społeczność, do której przynależy jednostka. Proces socjalizacji pierwotnej, podczas którego dziecko internalizuje wzory życia, a później proces socjalizacji wtórnej polegający na konfrontowaniu zdobytej wiedzy z postawami szerszej grupy - obydwa stanowią kluczowe etapy formowania tożsamości społecznej. J. Nikitorowicz opisuje przejście od uczestnictwa w rodzinie do uczestnictwa w szerszej zbiorowości w następujący sposób: „Jednostka w tym okresie odzwierciedla podstawowe wartości i formy współżycia subkultury, w której wzrastała (język, religię, obyczaje, zasady, normy postępowania, tradycje, sposoby organizacji czasu itp.). Identyfikacja z grupą odniesienia pozwala analizować jej wartości, normy i wzory przez nią reprezentowane, zrozumieć swoją sytuację społeczną oraz wynikające z niej konsekwencje dla jej zachowania"2.

Tożsamość jednostkowa charakteryzuje jednostkę, a bardziej precyzyjnie mówiąc, uwzględnia takie jej cechy, jak płeć czy wygląd, ale także jej osobowość, system wartości, wzory zachowań.

H. Mamzer, Tożsamość w podróży. Wielokulturowość a kształtowanie tożsamości jednostki, Poznań 2003, s. 100.

2 J. Nikitorowicz, Tożsamość w edukacyjnym procesie wielokulturowym, [w:] M. M. Orlińska (red.), Edukacja a tożsamość etniczna, Toruń 1995, s. 123-124. 
Tożsamość kulturowa, której konstruowanie możliwe jest dopiero po uprzednim zbudowaniu tożsamości społecznej i jednostkowej, H. Mamzer definiuje jako „identyfikację z wartościami niesionymi i propagowanymi przez kulturę danej zbiorowości społecznej, czyli internalizację określonych, postrzeganych $\mathrm{w}$ danej grupie norm i wartości oraz sposobów interpretowania zachowań i zdarzen”" »składników « rzeczywistości symbolicznej, kulturowego świata, pozwalający odróżnić siebie od Innych, swoich od obcych, zająć miejsce w przestrzeni społecznej (...)"14. Tożsamość kulturowa umożliwia jednostce określenie, do jakiej kultury przynależy, dlaczego należy właśnie do tej kultury i co stanowi pozamaterialne oznaki tej przynależności.

Tożsamość kulturową można zatem traktowaćjako podbudowę tożsamości narodowej, której podstawę stanowią właśnie czynniki kulturowe, o czym pisze Mirosław Sobecki, stwierdzając, że „solidne oparcie, jakie znaleźć można w rodzimej kulturze, pozwala jednostce w pełni zaakceptować siebie jako członka zbiorowości, która tę kulturę wytworzyła. Jednocześnie majacc poczucie siły wypływające z rodzimej kultury zdecydowanie łatwiej jest żyć w sytuacji, gdy funkcjonuje się w państwie z dominująca, inną niż rodzima, kulturą"5.

Szczególnego znaczenia nabiera konstruowanie tożsamości w warunkach zderzenia kultur, a więc w sytuacji, kiedy jednostka zostaje poddana działaniu mechanizmów akulturacji i asymilacji, których ostatecznym (negatywnym) rezultatem jest całkowite zastąpienie elementów kultury rodzimej przez elementy kultury obcej.

Zdaniem H. Malewskiej-Peyre wrastanie w nową kulturę wiąże się z przechodzeniem przez kolejne etapy. Pierwszym z nich jest etap fascynacji zastaną kulturą (kulturami), a dotyczy w szczególności przedstawicieli pierwszego pokolenia imigrantów, którzy opuścili kraj często wbrew swojej woli i próbują odnaleźć się w nowej rzeczywistości. Jednakże po pewnym czasie okazuje się, że niektóre jednostki nie są zdolne (ze względu na brak wystarczających kompetencji kulturowych) do funkcjonowania w nowym środowisku, co skutkować może pogłębiającą się alienacją $\mathrm{i}$ stopniowym wkraczaniem w obręb marginesu społecznego. Kolejny etap to refleksyjne analizowanie swojego położenia i poszukiwanie rozwiązań. Tożsamość następnych pokoleń imigrantów stanowi już połączenie elementów kultury rodziców i elementów kultury zastanej w państwie osiedlenia, które w wyniku procesów akulturacji i asymilacji zostały włączone w zakres własnego , ,ja" jednostki ${ }^{6}$.

Chociaż w kształtowaniu tożsamości ogromną rolę odgrywają różne agendy socjalizacyjne, w artykule uwaga zostanie skoncentrowana przede wszystkim na szkole, a ściślej rzecz ujmując, na szkole etnicznej oraz funkcjach, jakie spełnia w wychowaniu i edukacji dzieci polskich mieszkających poza granicami kraju.

\section{SZKOŁA ETNICZNA - NAJWAŻNIEJSZE FUNKCJE}

Szkoła jako instytucja wychowawcza odgrywa niezwykle doniosłą rolę w procesie wdrażania jednostek do uczestnictwa w życiu społecznym i kulturowym oraz w zażegnywaniu kryzysu tożsamości, pojawiającym się bardzo często w okresie dorastania, a który w warunkach pluralizmu kulturowego może ulec nasileniu i przedłużeniu.

$3 \quad$ H. Mamzer, Tożsamość w podróży..., dz. cyt., s. 107.

A. Szczurek-Boruta, Edukacja i odkrywanie tożsamości w warunkach wielokulturowości, Kraków 2007, s. 128

5 M. Sobecki, Funkcja etniczno- kulturowa szkót mniejszości narodowych, Białystok 1997, s. 32.

H. Malewska-Peyre, Ja wśród swoich i obcych, [w:] P. Boski, M. Jarymowicz, H. Malewska-Peyre, Tożsamość a odmienność kulturowa, Warszawa 1992, s. 18. 
D. Praszałowicz definiuje szkołę etniczną jako „szkołę zorganizowaną przez grupę etniczną (jej instytucje, organizacje lub osoby prywatne reprezentujące tę grupę) i dla grupy etnicznej"7. Nieco inaczej rzecz ujmuje M. Sobecki, pisząc, iż szkoła etniczna to „szkoła, w której czynnik narodowy ma większe znaczenie niż w szkole masowej, stanowiąc element konstytutywny. Jest to szkoła, która została utworzona w celu realizacji potrzeb określonej mniejszości narodowej, związanych z transmisją etnicznego dziedzictwa kulturowego" ${ }^{\prime 8}$.

Do czterech funkcji parafialnych szkół etnicznych w Stanach Zjednoczonych należy, zdaniem D. Praszałowicz, zaliczyć: funkcję ogólnowychowawcza, oświatowa, religijną oraz etniczną ${ }^{9}$. Kształtowanie osobowości, charakteru oraz postaw uczniów zgodnie z przyjętymi w danym społeczeństwie regułami i akceptowanymi społecznie oczekiwaniami należy do obszaru funkcji ogólnowychowawczej. Realizowana jest ona poprzez przekazywanie wychowankom określonych wzorów życia, systemu wartości i hierarchii tych wartości, norm zachowania i ogólnego światopoglądu. Funkcja oświatowa polega na przekazywaniu wiedzy z przedmiotów przewidzianych programem nauczania oraz ocenianiu postępów uczniów w zakresie jej opanowania. Można zatem powiedzieć, że celem funkcji oświatowej jest zdobycie wiedzy niezbędnej do poznania mechanizmów działających w świecie, a następnie poszerzanie horyzontów myślowych wychowanków. Kolejna funkcja - religijna - wiąże się z kształtowaniem i umacnianiem religijności uczniów. Ma ona kluczowe znaczenie w szkołach parafialnych, gdzie cały system edukacji i wychowania wypełniony jest pierwiastkami religijności (elementy religijności włącza się do zakresu wszystkich nauczanych przedmiotów, lekcje prowadzone są przez osoby duchowne itp.). Natomiast w szkołach etnicznych świeckich znaczenie tej funkcji pozostaje na podobnym poziomie, jak znaczenie pozostałych. Ostatnia funkcja, czyli etniczna, opiera się na kultywowaniu tradycji oraz wzmacnianiu identyfikacji uczniów z rodzimą kulturą. Realizowana jest ona przez nauczanie języka ojczystego, eksponowanie treści i wartości kultury etnicznej, pielęgnowanie tradycji etnicznych, organizowanie obchodów świąt narodowych, religijnych itp.

Warto jeszcze wspomnieć o dwóch funkcjach, które wypełnia szkoła etniczna.

Pierwszą z nich jest kształtowanie kompetencji kulturowych, które można określić jako wyposażenie jednostki (bądź grupy społecznej) w umiejętności umożliwiające pełne uczestnictwo w kulturze. T. Kostyrko podkreśla, że kompetencje kulturowe traktowane są „,nie tylko jako faktyczne przystosowanie do potencjalnego uczestnictwa w kulturze, ale także jako pewien stan rzeczy pożądany, »docelowy « ze względu na określone programy rozwoju kulturowego wspólnot narodowych, państwowych, a także ponadnarodowych"10.

Drugą niezwykle ważną funkcją szkoły etnicznej jest konstruowanie odpowiednich postaw o charakterze etnicznym. Jedną z najpełniejszych definicji postawy przedstawił S. Nowak, pisząc, iż „postawą pewnego człowieka wobec pewnego przedmiotu jest ogół względnie trwałych dyspozycji do oceniania tego przedmiotu i emocjonalnego nań reagowania oraz ewentualnie towarzyszących tym emocjonalno-oceniającym dyspozycjom względnie trwałych przekonań o naturze i własnościach tego przedmiotu"11. Przedmiotem postaw o charakterze etnicznym są

7 D. Praszałowicz, Amerykańska etniczna szkoła parafialna. Studium porównawcze trzech wybranych odmian instytucji, Wrocław 1986, s. 11.

8 M. Sobecki, Funkcja etniczno-kulturowa..., dz. cyt., s. 41.

9 D. Praszałowicz, Amerykańska etniczna szkoła parafialna. Studium porównawcze trzech wybranych odmian instytucji, Wrocław 1986, s. 25-26.

10 T. Kostyrko, Kompetencje kulturowe-zakres terminu, obszar problematyki, [w:] T. Kostyrko (red.), Kultura artystyczna a kompetencje kulturowe, Warszawa 1989, s. 8.

11 W. J. Goode, P. K. Hatt, Skala Bogardusa do pomiaru dystansu społecznego, [w:] S. Nowak, Metody badań socjologicz- 
przedstawiciele innych narodów, $\mathrm{w}$ stosunku do których można przejawiać pozytywne nastawienie - wówczas mówi się o postawach proetnicznych lub negatywne - wtedy chodzi o postawy antyetniczne ${ }^{12}$.

Próba nakreślenia roli szkoły etnicznej w życiu kolejnych pokoleń Polaków mieszkających zagranicą wydaje się niezbędna, gdyż to właśnie obecność tego rodzaju szkół warunkuje niejako możliwość wykorzystania podręczników szkolnych Polskiej Macierzy Szkolnej Zagranica, a co za tym idzie, określa ich miejsce i rolę $\mathrm{w}$ procesie edukacji i wychowania rzesz polskich dzieci mieszkających poza granicami ojczystego kraju. Należy jednak zauważyć, iż występuje tutaj swego rodzaju sprzężenie zwrotne: starając się bowiem zidentyfikować czynniki warunkujące realizację wymienionych wcześniej funkcji szkoły etnicznej, w żaden sposób nie można pominąć podręczników szkolnych, których zawartość i dostępność stanowią jeden z konstytutywnych elementów edukacji uczniów szkół polonijnych.

Specyfika nauczania w szkole etnicznej sprawia, że szczególna rola w wychowaniu i edukacji dzieci i młodzieży przypada podręcznikom szkolnym, które, z racji ograniczeń czasowych, z jakimi mają do czynienia uczniowie i nauczyciele w szkołach polonijnych, stają się podstawowym źródłem utrwalania zdobytej na zajęciach wiedzy i nabywania nowej, już we własnym zakresie. Rozwijaniu treści nauczania na lekcjach nie sprzyja sposób organizacji zajęć, które odbywają się raz na tydzień i trwają zaledwie kilka godzin. Dlatego też uczeń, który pragnie rozszerzyć zakres swojej wiedzy, zmuszony jest do samodzielnego poszukiwania wiadomości $\mathrm{i}$ interpretowania treści zawartych $\mathrm{w}$ różnego rodzaju pomocach naukowych, $\mathrm{w}$ tym zwłaszcza w podręcznikach szkolnych, które stanowią najbardziej dostępne źródło informacji (wyposażenie bibliotek polskich w poszczególnych krajach przedstawia się różnie w zależności od kraju i liczebności Polonii).

Charakter nauczania polonijnego implikuje zatem niebagatelne wyzwania dla autorów podręczników szkolnych oraz kadry pedagogicznej. Twórcy pomocy naukowych muszą bowiem uwzględnić wiele specyficznych uwarunkowań systemu szkolnictwa polonijnego i kierować się nieco innymi (czasem zupełnie odmiennymi) kryteriami doboru treści i sposobu ich formułowania. Skutkuje to wyjątkowym charakterem tego typu podręczników, których analiza prowadzi do ciekawych i inspirujących wniosków.

\section{SŁów Kilka o Polskiej Macierzy Szkolnej Zagranicą}

Aby w pełni zrozumieć istotę działalności Polskiej Macierzy Szkolnej Zagranica, należy wspomnieć najpierw o instytucji, którą można uznać za prekursora interesującej nas organizacji, a mianowicie o Polskiej Macierzy Szkolnej.

Asumptem do utworzenia jednego z najważniejszych stowarzyszeń edukacyjnych w historii polskiego szkolnictwa była tragiczna sytuacja polskiej oświaty i kultury na terenach zaboru rosyjskiego. Jak napisał J. Stemler, wieloletni dyrektor Polskiej Macierzy, , ,praca oświatowa stawała się apostolstwem narodowem ${ }^{\prime \prime 13}$ - to na społeczeństwie spoczywał obowiązek edukacji swoich obywateli. Próbę realizowania tego społecznego wyzwania stanowiło tajne nauczanie, które jednakże napotykało na swej drodze zbyt wiele przeszkód i utrudnień, aby mogło dotrzeć do obywateli. Jedyną szansą na wyprowadzenie społeczeństwa polskiego z zapaści edukacyjno-kultu-

nych, Warszawa 1965, s. 278

12 M. Sobecki, Funkcja etniczno- kulturowa..., dz. cyt., s. 41.

13 J. Stemler, Dar Narodowy na 3-go Maja. Polska Macierz Szkolna. Rys informacyjny o dwudziestoleciu działalności 19051925, Warszawa 1926, s. 16. 
rowej było założenie jawnej organizacji zajmującej się szeroko rozumianą oświatą. Tą organizacją była właśnie Polska Macierz Szkolna, której utworzenie spotkało się z ogromnym poparciem ze strony inteligencji, społeczników oraz życzliwym przyjęciem przez samo społeczeństwo.

Polska Macierz Szkolna ujawniła swoją działalność w 1905 roku, kiedy Rosja, doznawszy klęski na Dalekim Wschodzie, złagodziła nieznacznie twardą politykę rusyfikacyjną wobec obywateli polskich. Fakt ten pozwolił na podjęcie działań zmierzających do oficjalnego zarejestrowania organizacji. Uznanie przez władzę dawało jej wspaniałą szansę dotarcia do wszystkich ludzi, którzy złaknieni byli wiedzy i eliminowało jednocześnie szereg zagrożeń, jakie wiązały się z prowadzeniem tajnego nauczania, takich jak represje i więzienie uczniów i nauczycieli. Stowarzyszenie nobilitowało również zaangażowanie sławnych Polaków - dość powiedzieć, że pierwszym prezes Rady Nadzorczej został Henryk Sienkiewicz, zaś pierwszym prezesem Zarządu Głównego Antoni Osuchowski.

Polska Macierz Szkolna prowadziła swoją działalność do 1939 r. Wybuch II wojny światowej zmusił działaczy do przerwania budowania systemu polskiej oświaty. Mimo tego, że dorobek materialny tylu lat działalności został zniszczony - dorobek duchowy, kulturowy i oświatowy Macierzy przetrwał w postaci wielu wykształconych i świadomych obywateli, którzy w przyszłości mieli odbudowywać kraj. Niestety, po zakończeniu wojny, nie sposób było realizować niezależne od aparatu rządzącego inicjatywy oświatowe. Dlatego też, jak pisze A. Podhorodecka, „Polska Macierz Szkolna mogła się odrodzić i kultywować swoje ideały i zasady tylko na emigracji”'14.

14 maja odbył się w Londynie zjazd organizacyjny Polskiej Macierzy Szkolnej Zagranica, w którym uczestniczyło 116 osób, w tym wybitne osobistości życia emigracyjnego ${ }^{15}$. W dokumencie zawierającym wytyczne organizacyjne instytucji przyjętym na zebraniu założycielskim, któremu przewodniczył Władysław Anders znalazły się również założenia ideowe, do których należało „utrzymanie i pogłębianie świadomości religijnej i narodowej wśród ogółu Polaków, przede wszystkim zaś wśród dzieci i młodzieży; wychowanie młodego pokolenia $\mathrm{w}$ duchu wiary ojców, tradycji i kultury narodowej oraz wierności dla sprawy Niepodległości i Wolności Rzeczypospolitej Polskiej”16. Przyjęto wówczas statut ustanawiający Macierz w Wielkiej Brytanii i zawierający główny cel stowarzyszenia, czyli rozwój polskiej oświaty szkolnej i przedszkolnej, który miał być realizowany przez Koła Polskiej Macierzy Szkolnej Zagranicą (m.in. poprzez organizowanie nauczania religii i przedmiotów ojczystych oraz innych działań mających pogłębić świadomość narodową i religijną dzieci, tworzenie zespołów rodzicielskich, podejmowanie współpracy z miejscowym duchowieństwem, nauczycielami i organizacjami młodzieżowymi, urządzanie imprez dochodowych oraz zbiórek z okazji 3-go Maja ${ }^{17}$ ).

\section{Działalność wydawnicza Polskiej Macierzy Szkolnej Zagranicą}

Jak pisze A. Podhorodecka, brak podręczników i innych pomocy naukowych był odczuwalny już od samego początku istnienia organizacji i stanowił prawdziwe wyzwanie dla ludzi, którzy chcieli wychować świadomych swojego pochodzenia i tożsamości członków społeczności polskiej ${ }^{18}$. Rozumieli oni potrzebę stworzenia podręczników, które odpowiadałyby potrzebom

\footnotetext{
14 A. Podhorodecka, W stużbie oświacie. 50 lat Polskiej Macierzy Szkolnej, Londyn 2003, s. 21.

15 Protokół z zebrania organizacyjnego PMS odbytego dn. 14. maja 1953 r. w sali „Ogniska” w Londynie, APMS.

Wytyczne organizacyjne Polskiej Macierzy Szkolnej Zagranicą z 21. lipca 1952 r., APMS.

17 Projekt statutu Tymczasowego Polskiej Macierzy Szkolnej uchwalony na posiedzeniu Sekcji Prawno-Statutowej Komitetu Organizacyjnego PMS dn. 19. marca 1953 r., APMS.

18 A. Podhorodecka, W stużbie oświacie..., dz. cyt., s. 43.
} 
szkolnictwa polonijnego w Wielkiej Brytanii, gdyż książki i podręczniki przedwojenne, pochodzące z nakładów wydrukowanych w centralach w Londynie i w Jerozolimie ${ }^{19}$, okazywały się niedostosowane do warunków edukacji i życia Polaków w Anglii.

Dzięki podjętej w latach 50. i 60. akcji wydawniczej, Macierz dostarczyła zarówno uczniom, jak i nauczycielom bogatego materiału edukacyjnego, który pozwalał uczniom pogłębiać swoją wiedzę, a dla nauczycieli stanowił źródło wskazówek metodycznych i merytorycznych. Akcja ta obejmowała zarówno wydawanie podręczników do nauki języka polskiego, geografii, historii oraz religii, jak i drukowanie czasopism dla dzieci („,Dziatwa”), młodzieży (,,Razem młodzi przyjaciele”) oraz „Poradnika Metodycznego” dla kadry pedagogicznej, a także „Biuletynu Polskiej Macierzy Szkolnej Zagranicą", w którym umieszczane były m.in. sprawozdania z działalności towarzystwa.

O dynamicznym rozwoju tej płaszczyzny działalności instytucji, świadczy ilość publikowanych przez nią książek oraz zasięg ich terytorialnego kolportażu: A. Podhorodecka podaje, że w latach 1964-1966 zostało wydanych 30000 egzemplarzy podręczników i broszur (z tego $60 \%$ przekazano do innych skupisk polonijnych, zwłaszcza do Stanów Zjednoczonych ${ }^{20}$ ), zaś na przestrzeni lat 1966-1971 pojawiło się aż 24 nowe tytuły wydawnicze, których łączny nakład przekroczył 54000 egzemplarzy 21 (ogółem Polska Macierz Szkolna Zagranicą wydała do 1993 r. 59 różnych podręczników i broszur, których nakład wyniósł $150000^{22}$ ). Powyższą statystkę doskonale podsumowują słowa T. Radzika, który stwierdza, iż „,Wielka Brytania jest chyba jedynym krajem, gdzie szkolnictwo polonijne nie cierpi na brak podręczników, a nawet z Londynu właśnie szkoły polskie w świecie zasilane są wydawnictwami"23.

Działalność wydawnicza bez wątpienia jest jednym z najważniejszych aspektów funkcjonowania Macierzy. Stanowi ogniwo spajające inne płaszczyzny, na których prowadzi swoje prace organizacja. Gdyby nie istniały książi wydawane przez Macierz, wiedza dzieci polskich wychowywanych na obczyźnie, z dala od kraju, z którym miały tylko sporadyczny kontakt lub były go zupełnie pozbawione, byłaby na pewno uboższa.

\section{OgóLNA CHARAKTERYSTYKA ZEBRANYCH MATERIAŁÓW ŹRÓDŁOWYCH}

Zgromadzony latem 2009 r. materiał źródłowy obejmuje 32 podręczniki wydawane przez Polską Macierz Szkolną Zagranicą w okresie od jej ukonstytuowania się w Wielkiej Brytanii aż do $2008 \mathrm{r}$.

Wśród zgromadzonych pozycji znalazło się 21 podręczników polonistycznych, 5 podręczników przeznaczonych do nauki historii, 3 podręczniki do kształcenia geograficznego, 2 podręczniki ukazujące bogactwo dziedzictwa kulturowego Polski oraz jeden podręcznik do nauki religii.

Autorami podręczników wydawanych przez Polską Macierz Szkolną Zagranicą są różne osoby, ale w głównej mierze dominują nauczyciele związani ze środowiskiem szkół polonijnych. Sytuacja ta wydaje się być oczywista - to pedagodzy uczący w tego typu placówkach posiadają najlepszą wiedzę na temat specyfiki kształcenia i potrzeb dzieci polskich żyjących $w$ warunkach wielokulturowości.

Porównanie lat wydania poszczególnych podręczników pozwala stwierdzić, że najwięcej z nich powstało w latach 60. i 90., najmniej zaś po $2000 \mathrm{r}$. Wskazuje to na zmieniającą się rolę i zna-

19 T. Radzik, Szkolnictwo polskie w Wielkiej Brytanii, [w:] A. Koprukowniak (red.), Szkolnictwo polonijne na świecie po II wojnie światowej, Lublin 1980, s. 147.

20 A. Podhorodecka, W stużbie oświacie..., dz. cyt., s. 51

21 Tamże, s. 52

22 T. Radzik, Polska Macierz Szkolna Zagranica 1953-1993, Lublin 1995, s. 96.

23 T. Radzik, Szkolnictwo polskie..., dz. cyt., s. 147-148. 
czenie podręczników wydawanych przez wspominaną już wielokrotnie organizację polonijną w edukacji i wychowaniu dzieci polskich na emigracji. Początkowo, kiedy pojawiła się pierwsza fala wyjazdów do Wielkiej Brytanii, odgrywały one kluczową rolę, gdyż podręczniki krajowe były zupełnie niedostosowane do potrzeb nauczania polonijnego. Z czasem, kiedy w ojczyźnie coraz większą wagę zaczęto przywiązywać do sytuacji Polonii, zaczęły się pojawiać pomoce naukowe spełniające wymagania szkolnictwa polonijnego. Dlatego też Macierz stopniowo ograniczała ilość wydawanych przez siebie podręczników na rzecz korzystania z tych publikowanych w Polsce. Sytuacja ta nie zmienia jednak ogólnego znaczenia i nie pomniejsza roli podręczników tej instytucji w edukacji i wychowaniu kolejnych pokoleń uczniów szkół przedmiotów ojczystych.

Zgromadzony materiał źródłowy ukazuje dorobek PMSZ w zakresie wydawania podręczników. Należy podkreślić, iż trafiały one nie tylko do szkół polonijnych w Wielkiej Brytanii, ale służyły również uczniom z tego rodzaju placówek rozsianych po całym świecie.

\section{ROLA PODRĘCZNIKÓW PMSZ w EDUKACJI I WYCHOWANIU POLSKICH DZIECI \\ NA OBCZYŹNIE}

Rola podręczników Polskiej Macierzy Szkolnej Zagranicą w edukacji i wychowaniu polskich dzieci na obczyźnie będzie rozpatrywana w kontekście funkcji szkoły etnicznej wyróżnionych przez D. Praszałowicz. Poniżej przedstawione zostaną wybrane zakresy realizowania wymienionych wcześniej funkcji szkół etnicznych.

Stwierdzenie, iż omawiane tutaj pomoce naukowe z powodzeniem realizują funkcję ogólnowychowawcza, nie powinno wywoływać żadnych wątpliwości. Czynią to poprzez poruszanie takich zagadnień, jak kształtowanie tożsamości rozumianej jako ciągłe poszukiwanie siebie i podejmowanie prób zdefiniowania siebie $\mathrm{w}$ kontekście warunków, w jakich znalazła się dana jednostka (wiersz Wincentego Pola A czy znasz ty... zamieszczony w Wypisach M. Goławskiej²4), ale pokazywanej również jako proces wysoce problematyczny dla dziecka funkcjonującego w warunkach wielokulturowości (np. w czytance Marcin odnajduje siebie ${ }^{25}$, której bohaterem jest młody chłopiec walczący z wewnętrznym rozdarciem swojej osobowości pomiędzy dwie narodowości: niemiecką i polska, uczniowie mogą odnaleźć nawiązania do swojej sytuacji) oraz tematów związanych z kształtowaniem pozytywnych postaw etnicznych, przejawiających się m.in. w tolerancyjnym podejściu do kultury i obyczajowości członków innych narodów (przykładem takich tekstów są Papużki i gotę̨bie ${ }^{26}$ czy Główna wygrana ${ }^{27}$, które traktują o przyjaźni pomiędzy polskimi dziećmi mieszkającymi poza granicami rodzinnego kraju a najmłodszymi obywatelami innych krajów). Innym ważnym obszarem tematycznym, poruszanym przez podręczniki Polskiej Macierzy Szkolnej Zagranicą w ramach realizacji funkcji ogólnowychowawczej, są zagadnienia odnoszące się do rodziny. Z jednej strony autorzy czytanek kładą nacisk na konieczność okazywania szacunku oraz wartość, jaką powinna dla każdego Polaka przedstawiaćjego rodzina i krąg najbliższych (przykładem może być tutaj Wiersz o matce ${ }^{28}$ ), z drugiej zaś prezentują nieco stereotypowe podejście do ról społecznych - ojciec to główny żywiciel rodziny i jej władca, a rola

24 W. Pol, A czy znasz ty..., [w:] Wypisy. Podręcznik do nauki języka polskiego dla klasy V, Londyn 1979, s. 5.

25 M. Dąbrowska, Marcin odnajduje siebie, [w:] W kręgu dzielności i pracy. Podręcznik do nauki języka polskiego dla klasy VI, Londyn 1966, s. 90-92.

26 M. Dubanowiczowa, Papużki i gołębie, [w:] Moja czytanka. Podręcznik na klasę III (dla dzieci od lat 8 do 9), Londyn 1964, s. 99- 100

27 Z. Kozarynowa, Główna wygrana, [w:] tamże, s. 113-114.

28 L. Marjańska, Wiersz o matce, [w:] Mój język ojczysty. Czytanka dla klas IV szkót przedmiotów ojczystych, Londyn 1993, s. $127-128$. 
matki sprowadzana jest do opiekowania się ogniskiem domowym (Henio $z$ Łodzi ${ }^{29}$ ). Na kartach podręczników szkolnych zostały poruszone także takie tematy, jak wspólne działanie dla dobra ogółu, angażowanie się w życie społeczne i aktywność społeczna. Inaczej rzecz ujmując, książki Polskiej Macierzy Szkolnej Zagranicą skłaniają uczniów do refleksji nad zagadnieniem postawy obywatelskiej lub skutkami, jakie może wywołać jej brak (m.in. do zagadnień tych odwołują się takie czytanki, jak Szkota rycerska ${ }^{30}$ czy odwoływanie się do takich inicjatyw społecznych, jak Wielka Orkiestra Świątecznej Pomocy ${ }^{31}$ ). Wśród innych treści, które poruszają podręczniki można odnaleźć m.in. tematy dotyczące pracy i pracowitości, konieczności okazywania szacunku starszym pokoleniom i ich dorobkowi, szczytnego celu, jakim jest pomaganie i poświęcanie się dla innych oraz wiele innych, o których z powodu braku miejsca nie sposób tu nawet wspomnieć.

Analiza wybranych podręczników Polskiej Macierzy Szkolnej Zagranicą pokazuje, że funkcja wychowawcza realizowana jest $\mathrm{w}$ nich za pomocą bardzo różnorodnych środków przekazu, co przejawia się w wielości czytanek nawiązujących do wartości, norm, stylów życia i światopoglądów oraz kształtowania tożsamości. Uczniowie szkół polonijnych, którzy podczas zajęć (a także $\mathrm{w}$ domu) korzystają z książek Macierzy i omawiają wspólnie z nauczycielem zawarte w nich teksty, mają okazję zapoznać się z treściami, które mogą stać się podstawą ich działania w stosunku do innych ludzi. Powtarzanie pewnych prawd, zasad i norm w kolejnych czytankach utrwala przekaz i sprawia, że wzrasta prawdopodobieństwo, iż dzieci i młodzież zinternalizują te treści i uczynią z nich kanon swoich wartości, którymi będą się kierować w swoim życiu.

Przekazywanie wiedzy, a więc realizowanie szeroko pojętej funkcji oświatowej, należy do najważniejszych wymiarów treściowych analizowanych podręczników, które zawierają niezwykle bogatą gamę różnorodnych informacji, które niejako poszerzają zakres wiedzy zdobytej w szkołach angielskich o wiadomości powiązane z rodzimą kultura, zwyczajami, historią i wartościami. Treści odnoszące się do faktów i procesów historycznych można utożsamić z jednym z najważniejszych wymiarów realizowania przez omawiane podręczniki funkcji oświatowej. Na kartach książek autorzy prezentują wielkie bitwy (bitwa pod Grunwaldem przedstawiona została jako wiekopomny dowód męstwa Polaków w Polska za Jagiellonów M. Goławskiego ${ }^{32}$ ), mądrych władców oraz mechanizmy i zjawiska, które doprowadzily do upadku Rzeczypospolitej (jak miało to miejsce, zdaniem M. Łuczkiewicz i B. O’Driscoll, w przypadku „złotej wolności" ${ }^{\prime 33}$, której rozumienie zostało wypaczone przez polską szlachtę). Autorzy omawiają także sylwetki znakomitych Polaków - nie ograniczają się przy tym wyłącznie do zamierzchłych czasów, ale podkreślają rolę współczesnych wielkich postaci takich, jak Lech Wałęsa oraz Jan Paweł II czy sportowców pokroju Adama Małysza czy Roberta Kubicy. Podręczniki kształtują również wiedzęi i postawę uczniów Szkół Sobotnich wobec dziedzictwa narodowego, które ukazywane jest zarówno przez pryzmat reprodukcji dzieł polskich malarzy i artystów, jak i poprzez charakterystykę sylwetek najsławniejszych polskich twórców, którzy urastają do rangi symbolu polskości, o czym świadczyć może następujący cytat zaczerpnięty z czytanki Koncert Chopina w Paryżu: „I powiem szczerze, że zazdroszczę Polsce takiego geniusza, takiego obrońcy przed światem. Bo waszych poetów i pisarzy zrozumie tylko ten, kto zna język polski. Chopin zaś jest i będzie zrozumiały dla wszystkich

29 H. Mortkowiczówna, Henio z Eodzi, [w:] Moja czytanka...., dz. cyt., s. 79.

30 A. Chołoniewski, Szkoła rycerska, [w:] Wypisy..., dz. cyt., s. 6-8.

31 B. O'Driscoll, Dla polskiego ucznia. Podręcznik do nauki języka polskiego w szkotach przedmiotów ojczystych, Londyn 2008 , s. 25 .

32 M. Goławski, Polska za Jagiellonów. Opowiadania i legendy historyczne dla dzieci szkót polskich na obczyźnie, Londyn 1972, s. 9-11.

33 M. Łuczkiewicz, B. O’Driscoll, Historia Polski (od Lecha do Lecha), Londyn 2000, s. 46. 
i wzruszy każdego, ktokolwiek usłyszy jego muzykę. To geniusz, to wielki geniusz. Potężny jest naród, którego muzyka potrafiła takim głosem przemówić do serca ludzkości całej"34.

Szkoły przedmiotów ojczystych realizują również wcześniej już wspomnianą funkcję etniczną. Narzędziem służącym urzeczywistnianiu tej funkcji są m.in. podręczniki szkolne. Książki wydawane przez Polską Macierz Szkolną Zagranicą zawierają teksty dotyczące kultywowania i znaczenia tradycji w życiu Polaków, roli mowy ojczystej, a także treści i wartości kultury rodzimej, które można z powodzeniem, moim zdaniem, zamknąć w triadzie Bóg - Honor - Ojczyzna. Funkcja religijna zawiera się niejako w funkcji etnicznej, gdyż w społeczeństwie polskim religia włączona jest $\mathrm{w}$ obręb wartości typowo polskich, dlatego też nie będzie dodatkowo omawiana. Podręczniki uczą zarówno podstaw mowy ojczystej (zasad pisowni, gramatyki, interpunkcji), ale jednocześnie starają się ukazać jej znaczenie i wartość, jaką stanowi dla Polaków, co artykułuje m.in. tekst omawiający obronę języka polskiego przez grupkę uczniów z małej szkoły we Wrześni ${ }^{35}$. Realizacja funkcji etnicznej opiera się również na przedstawianiu treści nawiązujących do wspomnianej już wcześniej triady Bóg - Honor - Ojczyzna. Podręczniki perswadują uczniom, jak wielkim szczęściem jest posiadanie własnej ojczyzny i jak wiele zawdzięczają jej całe rzesze ich rodaków. Walka za kraj rodzinny prezentowana jest jako dowód miłości do kraju rodzinnego i najwspanialsza cnota oraz przejaw honorowej postawy - aspekt ten porusza m.in. wiersz Do moich synó $w^{36}$, w którym autor apeluje do swoich potomków, aby nie zniweczyli wysiłku swoich przodków, którzy ofiarowali swoje życie za rodzinny kraj. O znaczeniu wiary religijnej (co ciekawe konsekwentnie utożsamianej wyłącznie z katolicyzmem) w życiu Polaków mówi m.in. wiersz Matka Boska Częstochowska ${ }^{37}$. Autorzy dążą do wypracowania w uczniach postawy, której podbudową byłaby wiara oraz kluczowe rodzime wartości, do których zaliczają się: tradycje polskie, polska kultura, język ojczysty oraz szereg innych elementów.

\section{Próba PODSUMOWANIA - NAJWAŻNIEJSZE WNIOSKI}

Na zakończenie warto przytoczyć kilka syntetycznych wniosków.

Po pierwsze, przewaga podręczników szkolnych wydanych w latach 60. i 70. wyraźnie wskazuje, że to ta grupa książek odegrała największą rolę w procesie edukacji i wychowania uczniów szkół polonijnych. To właśnie na pokolenie wychowanków uczęszczających do polskich placówek w tamtym okresie najbardziej oddziaływały podręczniki szkolne wydawane przez Polską Macierz Szkolną Zagranica. Wpływ ten dodatkowo wzmacniał fakt braku lub niewielkiego dostępu do innych źródeł wiedzy. Po 1990 roku wyraźnie zmalała liczba podręczników wydawanych przez jedną z najważniejszych organizacji polonijnych. Najprawdopodobniej wynika to z systematycznego wprowadzania udogodnień w nawiązywaniu kontaktów z krajem (w tym z instytucjami odpowiedzialnymi za edukację polonijną) oraz uwzględniania specyfiki prowadzenia nauczania $\mathrm{w}$ warunkach emigracji przez autorów krajowych podręczników szkolnych, którzy wcześniej zdawali się ignorować fakt istnienia szczególnych potrzeb edukacji polonijnej. Obecnie szkoły przedmiotów ojczystych korzystają w głównej mierze z pomocy naukowych redagowanych i wydawanych w kraju. Podkreślić jednakże należy, że nie oznacza to, że podręczniki szkolne Polskiej Macierzy Szkolnej Zagranicą oddziaływały na proces wychowa-

34 S. Wasilewski, Koncert Chopina w Paryżu, [w:] Wypisy..., dz. cyt., s. 59.

35 M. Mossoczowa, W niemieckiej szkole, [w:] W kręgu dzielności i pracy. Podręcznik do nauki języka polskiego dla klasy VI, Londyn 1966, s. 66-67.

36 J. Żuławski, Do moich synów, [w:] Wypisy..., dz. cyt., s. 82.

37 J. Lechoń, Matka Boska Czestochowska, [w:] tamże, s. 13-14. 
nia i edukacji uczniów polskich placówek wyłącznie w pewnym okresie czasu. Ich wpływ na dzisiejsze pokolenie wiąże się $\mathrm{i}$ jednocześnie wynika z przekazu międzypokoleniowego i procesów socjalizacji prowadzonych przez rodziców i najbliższych krewnych wychowanków szkół sobotnich, których edukacja opierała się właśnie na tych podręcznikach. Przyswoiwszy zawarte w nich wiadomości, odnoszące się do określonych postaw, wartości i wiedzy, przekazywali je następnie (poprzez socjalizację pierwotną) swoim dzieciom i wnukom. Można więc stwierdzić, że bezpośredni udział w edukacji i wychowaniu polskich dzieci i młodzieży miały podręczniki szkolne Polskiej Macierzy Szkolnej Zagranicą do lat 90 . Po tym okresie rola tych pomocy naukowych zmienia się stopniowo i przybiera charakter pośredni.

Po drugie, podręczniki szkolne z powodzeniem realizują wszystkie funkcje przynależne szkołom przedmiotów ojczystych, a więc funkcję ogólnowychowawcza, oświatową etniczną oraz religijną. Możliwość urzeczywistniania wymienionych funkcji wynika z ogromnej ilości zróżnicowanego materiału zawartego w książkach, uzupełnionego dodatkowo o niezwykle bogaty materiał graficzny (np. reprodukcje obrazów, zdjęcia, ryciny, ilustracje), co ułatwia realizowanie zadań przypisanych szkołom polonijnym. Daje również nauczycielom możliwość swobodnego doboru materiału dydaktycznego, stanowiącego podstawę poszczególnych lekcji. Będąc narzędziem wcielania w życie opisywanych funkcji, podręczniki oferują wiele tekstów, które poruszają niezwykle szeroki wachlarz zagadnień: począwszy od tych najprostszych i najbardziej przystępnych dla uczniów, które omawiane są zazwyczaj w konwencji zabawy, poprzez te o średnim stopniu trudności, aż do najbardziej skomplikowanych i rozbudowanych, których objaśnienie wymaga udziału wychowawcy. Pozawala to jednakże na dostosowywanie materiału do umiejętności i potrzeb uczniów i daje możliwość dostosowywania treści do poziomu grupy. Bogactwo materiału można traktować również w kategoriach bodźca motywującego dzieci i młodzież do nauki w domu. Występuje także tendencja do łączenia funkcji w ramach jednej czytanki lub tekstu, co, ze względu na ich podobieństwo i zakres treściowy, wydaje się naturalną metodą na przekazywanie uczniom jak największej ilości wiedzy w jednej jednostce tekstowej.

Po trzecie, analiza podręczników szkolnych wydawanych przez Polską Macierz Szkolną Zagranicą wykazała, że autorzy starają się zachować bezstronność w prezentowaniu treści, ale w pewnych momentach, stosując odpowiedni język, na który składają się przede wszystkim pełne zabarwienia emocjonalnego sformułowania perswazyjne, narzucają swój światopogląd oraz sposób interpretowania zjawisk i zdarzeń. Selektywny dobór materiału posiada zatem znamiona wywierania wpływu na uczniów, kształtowania ich postaw i świadomości według własnych wzorców. Czytanki dobrane są bowiem w taki sposób, aby ukazywać Polskę i Polaków w jak najlepszym świetle. Oczywiście ma to podłoże w narodowym patriotyzmie autorów, ale odbiera uczniom możliwość wieloaspektowego spojrzenia na dane zagadnienie i rozważenia kilku punktów widzenia. Utrwala to w dzieciach i młodzieży obraz doskonałej ojczyzny, ale nie uświadamia istnienia ciemnych kart $\mathrm{w}$ historii Rzeczypospolitej oraz momentami nagannych postaw przejawianych przez naród polski. Są to problemy niezwykle trudne do omówienia na lekcjach i należy je prezentować z ogromnym wyczuciem połączonym z obiektywizmem, ale budowanie w uczniach miłości do kraju nie powinno być oparte na tworzeniu jej zafałszowanego wizerunku. Wychowankowie muszą zdawać sobie sprawę z istnienia słabych stron Rzeczypospolitej, by móc skoncentrować się na mocniejszych i umiejętnie bronić kraju np. podczas dyskusji z rówieśnikami ze szkół angielskich.

Po czwarte, można stwierdzić, że podręczniki szkolne wydawane przez Polską Macierz Szkolną Zagranicą eksponują do pewnego stopnia stereotypowe wzory, a mianowicie stereotyp Polaka 
- katolika oraz stereotypowe podziały ról ze względu na płeć. Nie sposób zaprzeczyć, że ogromna większość narodu polskiego należy do rzymskokatolickiego wyznania wiary, jednakże nie oznacza to, że wszyscy Polacy są katolikami. Tymczasem w książkach szkolnych narodowość polska konsekwentnie utożsamiana jest z katolicyzmem. Podobnie, jeśli chodzi o kreowanie wizerunku kobiety i mężczyzny, to zawsze kobieta jest tą osoba, która zajmuje się domem i dziećmi, a mężczyzna pełni funkcję głowy rodziny. Wprowadzanie takich stereotypowych wizerunków jest o tyle zrozumiałe, że niewielka ilość czasu, jaką uczniowie spędzają w szkołach sobotnich zmusza do ograniczania materiału. Poza tym, w czasach i warunkach, w których powstawały podręczniki nikt nie zaprzątał sobie głowy kwestiami równouprawnienia płci czy równości wyznań w Rzeczypospolitej. Ideologie te nie były zresztą prawie w ogóle rozpowszechnione, gdyż społeczeństwo polskie borykało się wówczas z problemami innej natury, a działacze emigracyjni walczyli o zachowanie polskiej tożsamości wśród młodego pokolenia. Wiedza potoczna stanowiła podstawowe źródło informacji, a obraz Polaka jako gorliwego katolika i przedstawiony wyżej podział zadań pomiędzy kobiety i mężczyzn uznawane były za zjawiska naturalne i prawdziwe. Z drugiej jednakże strony, taki sposób ujmowania pewnych treści prowadzić mógł do ich utrwalenia w świadomości dzieci i młodzieży oraz późniejszego wcielania w życie. Stąd ogromną rolę odgrywali rodzice i nauczyciele, którzy uzupełniali przekaz podręczników o dodatkowe informacje.

Po piąte, wśród podręczników szkolnych największą grupę stanowią te do nauki języka polskiego. Jest to o tyle zrozumiałe, że język polski stanowi najważniejszy przedmiot nauczany w szkołach sobotnich Bez edukacji w zakresie nauki czytania, pisania, mówienia i rozumienia mowy ojczystej szkoły polonijne nie miałyby racji bytu, gdyż całość prowadzonego w nich nauczania opiera się na języku polskim. Poza tym, należy podkreślić, że to mowa ojczysta w głównej mierze kształtuje tożsamość narodowa gdyż to za jej pomocą przekazywane są dalsze komunikaty odnoszące się do Polski i szeroko rozumianej polskości, a więc informacje dotyczące bogactwa naturalnego i kulturowego, tradycii, zwyczajów, historii i wielu innych dziedzin.

\section{LITERATURA PODMIOTU}

Chołoniewski A., Szkoła rycerska, [w:] Wypisy. Podręcznik do nauki języka polskiego dla klasy V, Londyn 1979.

Dąbrowska M., Marcin odnajduje siebie, [w:] W kręgu dzielności i pracy. Podręcznik do nauki języka polskiego dla klasy VI, Londyn 1966.

Dubanowiczowa M., Papużki i gołębie, [w:] Moja czytanka. Podręcznik na klasę III (dla dzieci od lat 8 do 9), Londyn 1964.

Goławski M., Polska za Jagiellonów. Opowiadania i legendy historyczne dla dzieci szkót polskich na obczyźnie, Londyn 1972.

Kozarynowa Z., Główna woygrana, [w:] Moja czytanka. Podręcznik na klasę III (dla dzieci od lat 8 do 9), Londyn 1964.

Lechoń J., Matka Boska Częstochowska, [w:] Wypisy. Podręcznik do nauki języka polskiego dla klasy V, Londyn 1979.

Łuczkiewicz M., O'Driscoll B., Historia Polski (od Lecha do Lecha), Londyn 2000.

Marjańska L., Wiersz o matce, [w:] Mój język ojczysty. Czytanka dla klas IV szkót przedmiotów ojczystych, Londyn 1993.

Moja czytanka. Podręcznik na klase III (dla dzieci od lat 8 do 9), Londyn 1964.

Mortkowiczówna H., Henio z Łodzi, [w:] Moja czytanka. Podręcznik na klasę III (dla dzieci od lat 8 do 9), Londyn 1964.

Mossoczowa M., Wniemieckiej szkole, [w:] Wkręgu dzielności i pracy. Podręcznik do nauki języka polskiego dla klasy VI, Londyn 1966.

Mytko D. (oprac.), Mój język ojczysty. Czytanka dla klas IV szkół przedmiotów ojczystych, Londyn 1993.

O’Driscoll B., Dla polskiego ucznia. Podręcznik do nauki języka polskiego w szkołach przedmiotów ojczystych, Londyn 2008.

Pol W., A czy znasz ty..., [w:] Wypisy. Podręcznik do nauki języka polskiego dla klasy V, Londyn 1979.

Projekt statutu Tymczasowego Polskiej Macierzy Szkolnej uchwalony na posiedzeniu Sekcji Prawno-Statutowej Komitetu Organizacyjnego PMS dnia 19 marca 1953 roku, APMS.

Protokół z zebrania organizacyjnego PMS odbytego dnia 14 maja 1953 roku w sali Ogniska w Londynie, APMS.

Wasilewski S., Koncert Chopina w Paryżu, [w:] Wypisy. Podręcznik do nauki języka polskiego dla klasy V, Londyn 1979.

W kręgu dzielności i pracy. Podręcznik do nauki języka polskiego dla klasy VI, Londyn 1966. 
Wypisy. Podręcznik do nauki języka polskiego dla klasy V, Londyn 1979.

Wytyczne organizacyjne Polskiej Macierzy Szkolnej Zagranicą z 21 lipca 1952r., APMS.

Żuławski J., Do moich synów, [w:] Wypisy. Podręcznik do nauki języka polskiego dla klasy V, Londyn 1979.

\section{LITERATURA PRZEDMIOTU}

Boski P., Jarymowicz M., Malewska-Eyre H., Tożsamość a odmienność kulturowa, Warszawa 1992

Goode W. J., Hatt P. K., Skala Bogardusa do pomiaru dystansu społecznego, [w:] Nowak S., Metody badań socjologicznych, Warszawa 1965

Koprukowniak A. (red.), Szkolnictwo polonijne na świecie po II wojnie światowej, Lublin 1980.

Kostyro T. (red.), Kultura artystyczna a kompetencje kulturowe, Warszawa 1989.

Kostyro T., Kompetencje kulturowe - zakres terminu, obszar problematyki, [w:] Kostyro T. (red.), Kultura artystyczna a kompetencje kulturowe, Warszawa 1989.

Malewska-Eyre H., Ja wśród swoich i obcych, [w:] Boski P., Jarymowicz M., Malewska- Eyre H., Tożsamość a odmienność kulturowa, Warszawa 1992.

Mamzer H., Tożsamość w podróży. Wielokulturowość a kształtowanie tożsamości jednostki, Poznań 2003.

Nikitorowicz J., Tożsamość w edukacyjnym procesie wielokulturowym, [w:] Orlińska M. M.(red.), Edukacja a tożsamość etniczna, Toruń 1995.

Nowak S., Metody badań socjologicznych, Warszawa 1965.

Orlińska M. M. (red.), Edukacja a tożsamość etniczna, Toruń 1995.

Podhorodecka A., W stużbie oświacie. 50 lat Polskiej Macierzy Szkolnej, Londyn 2003.

Praszałowicz D., Amerykańska etniczna szkoła parafialna. Studium porównawcze trzech wybranych odmian instytucji, Wrocław 1986.

Radzik T., Polska Macierz Szkolna Zagranica 1953-1993, Lublin 1995.

Radzik T., Szkolnictwo polskie w Wielkiej Brytanii, [w:] Koprukowniak A. (red.), Szkolnictwo polonijne na świecie po II wojnie światowej, Lublin 1980.

Sobecki M., Funkcja etniczno-kulturowa szkót mniejszości narodowych, Białystok 1997.

Stemler J., Dar Narodowy na 3-go Maja. Polska Macierz Szkolna. Rys informacyjny o dwudziestoleciu działalności 1905-1925, Warszawa 1926.

Szczurek-Boruta A., Edukacja i odkrywanie tożsamości w warunkach wielokulturowości, Kraków 2007.

\section{Słowa kluczowe}

Polska Macierz Szkolna Zagranica, podręczniki, wychowanie, edukacja, polskie dzieci na obczyźnie

\section{StreszCZenie}

Edukacja i wychowanie dzieci jest jednym z najważniejszych zadań, jakie stoją przed rodzicami, szkołą i szeroko pojętym środowiskiem społecznym. Zadanie to komplikuje się szczególnie w warunkach wielokulturowości, z którymi mamy do czynienia w przypadku zamieszkiwania w innych krajach. Ruchy migracyjne przyczyniają się do tego, że dzieci i młodzież wychowywane są w otoczeniu, w którym mieszają się różne wzorce kulturowe i odmienne style życie. Nie zawsze rodzime wzorce są stawiane na pierwszym miejscu - o to, aby rodzime wartości i polska kultura nie zostały zapomniane w rodzinach polskich emigrantów dbają instytucje polonijne, zaś w szczególności polonijna organizacja oświatowa Polska Macierz Szkolna Zagranica.

Polska Macierz Szkolna jest jedną z wielu organizacji polonijnych działających na terenie Wielkiej Brytanii. Będąc jedną z najstarszych organizacji polonijnych, przyczynia się przede wszystkim do podtrzymywania ducha polskości w kolejnych pokoleniach polskich emigrantów. Jej działalność w dużej mierze poświęcona jest prowadzeniu Szkół Polskich, w których polskie dzieci od ponad 60 lat mogą uczyć się języka polskiego, polskiej historii i geografii.

Jednym z najważniejszych aspektów działalności Polskiej Macierzy Szkolnej Zagranicą jest wydawanie podręczników, z których korzystają wychowankowie Szkół Polonijnych na całym 
świecie. Treści podręczników odwołują się do polskich wartości i kultury, które za ich pośrednictwem trafiają do wychowanków Szkół Polonijnych. Teksty poruszają tak ważne zagadnienia, jak kształtowanie tożsamości, tolerancja, szacunek dla dorobku przeszłych pokoleń, postawa obywatelska, znaczenie języka polskiego w życiu polskich emigrantów, zwyczaje świąteczne i wiele innych. Tym samym odgrywają ogromną rolę w edukacji i wychowaniu kolejnych pokoleń polskich dzieci mieszkających poza granicami Polski. Rola podręczników szkolnych Polskiej Macierzy Szkolnej Zagranica pozostaje nieoceniona.

\section{Textbooks of Polska Macierz Szkolna Zagranica

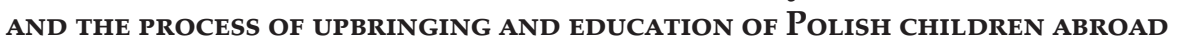

\section{Keywords}

Polska Macierz Szkolna Zagranica, textbooks, upbringing, education, Polish children abroad

\section{Summary}

Children's education and upbringing are one of the most significant tasks facing parents, school and widely understood social environment. This task becomes complicated especially in the circumstances of multiculturalism arousing in the situation of living abroad. Due to migrations children and the youth are brought up in the environment of different cultural patterns and lifestyles mixing together. Not always domestic patterns are prioritized - various institutions of the Polish diaspora, especially educational organization called Polska Macierz Szkolna Zagranica, take care of reminding Polish emigrants' families about Polish values and culture.

Polska Macierz Szkolna Zagranicą is one of numerous Polish organizations working in Great Britain. As one the oldest institutions of the Polish diaspora, it contributes above all to developing Polish spirit in succeeding generations of Polish emigrants. Its activities are chiefly connected to founding and maintaining Szkoły Polskie (Polish Schools) in which Polish emigrants' children have been learning Polish language, history and geography for above 60 years.

One of the most important aspects of the organization's activities is releasing schoolbooks for students of Szkoły Polonijne (The Polish Disapora's Schools) all over the world. Contents of the books refer to Polish values and culture and in this way appeal to students of Szkoły Polonijne. The schoolbooks contain texts on many significant issues, such as building self-identity, tolerance, respect to past generations' achievements, civic attitude, the role of Polish language in Polish emigrants' lives, Polish holiday traditions and many more. In this way they play unquestionable role in education and upbringing of subsequent generations of Polish children abroad.

The role of the organization's textbooks remains unparalleled. 